\title{
STABILITY OF INTERLOCKED PATTERN PLACED BLOCK REVETMENTS
}

\author{
Fabian Gier ${ }^{1}$, Holger Schüttrumpf ${ }^{2}$, Jens Mönnich ${ }^{3}$, Jentsje van der Meer ${ }^{4}$, Matthias Kudella \\ and Hillel Rubin ${ }^{6}$
}

Revetments protect the shorelines of coasts, estuaries and rivers against wind waves, ship waves, currents and ice attacks. The resistance of revetments basically depends on the properties of the cover layer. In the case of an interlocked pattern placed revetment the resistance essentially depends on the weight of the individual blocks, the friction forces and the interlocking force. In this study, extensive large scale model tests have been performed to assess the hydraulic stability of interlocked pattern placed revetments. The study shows test results due to deformations, wave loading and pull-out tests. Overall, the experimental results show a significant increase in the structural stability of the revetment against wave attack due to the interlocking system compared to traditional revetment elements.

Keywords: interlocking blocks; stability; large scale model tests

\section{Introduction}

Revetments are generally used to protect the embankments of coastal areas, estuaries and rivers against wind and ship waves, currents and ice attacks and the resulting erosion. The stability of revetments fundamentally depends on the performance of the cover layer. Concerning the construction of the cover layer, revetments are differentiated as rubble, monolithic and block placed revetments, in which the group of placed block revetments can be subdivided into interlocked and loose placed block revetments. The following paragraphs primarily concern interlocked placed block revetments.

Regarding the interlocked placed block revetments (PIANC, 2011) single blocks are force-locked over a horizontal, a vertical or a double bond structure (EAK, 1993). It is assumed, that the application of an interlocking system produces an increase in stability against wave induced load compared to loose block revetments. The stability of revetments includes several different requirements. Relating to the hydraulic stability the following hydro-engineering requirements can be found in the associated literature (EAK 2003, EAU 2004, Hansen 1985):

1. Resistance against external wave load due to wave impact

2. Resistance against uplift due to the wave run down

3. Resistance against erosion of material of the sub-layers

4. Resistance against liquefaction of the subsoil

5. Adaptability to local settlements of the subsoil

6. Maintenance of residual resistance after an occurring damage, e.g. vandalism, in order to have enough time for maintenance work

Nowadays, ecological and economic issues are additional demands besides the listed hydroengineering requirements (PIANC 2011). Revetments should be cost-effective in the construction as well in the maintenance. This leads to a demand of cost minimization over the lifetime of revetments. Furthermore, revetments should be ecologically valuable, in order to form a habitat for plants and animals. Due to this demand additional requirements result on the porosity and surface structure.

Fundamentally, interlocked placed block revetments are able to fulfill the hydro-engineering requirements as well as the ecologically and economic issue. With particular regard to the economic issue interlocked placed block revetments seem to be a suitable approach due to the single-layer

${ }^{1}$ Institute for Hydraulic Engineering and Water Resources Management, RWTH Aachen University, Mies-van-derRohe-Straße 1, 52056 Aachen, Germany, e-mail: gier@iww.rwth-aachen.de

2 Institute for Hydraulic Engineering and Water Resources Management, RWTH Aachen University, Mies-van-derRohe-Straße 1, 52056 Aachen, Germany, e-mail: schuettrumpf@iww.rwth-aachen.de

${ }^{3}$ Berding Beton GmbH, Industriestraße 6, 49439 Steinfeld, Germany, e-mail: moennich@berdingbeton.de

${ }^{4}$ Van der Meer Consulting B.V, Voorsterweg 28, 8316 PT Marknesse, The Netherlands, e-mail: jm@vandermeerconsulting.nl

${ }^{5}$ Coastal Research Centre (FZK) of Leibniz University Hannover and TU Braunschweig, Merkurstr. 11, 30419 Hannover, Germany, e-mail: kudella@fzk-nth.de

${ }^{6}$ Faculty of Civil and Environmental Engineering, Technion - Israel Institute of Technology, Haifa 3200, Israel, e-mail: hrubin@techunix.technion.ac.il 
placement and thereby the reduced material requirements in comparison to rubble mound revetments, for example.

As depicted in Figure 1 the stability of interlocked block placed revetments against external loading depends on the self-weight force $F_{G}$ of the single block, the friction force $F_{R, B}$ between the single blocks, the friction force $F_{R, S}$ between the blocks and the sub-layer, and the interlocking force $\mathrm{F}_{\mathrm{I}}$. If the sum of the presented forces is larger than the uplift force $F_{L}$ due to wave loading, the revetment can be rated as stable.

The magnitude of the interlocking force, which represents the increase in stability compared to loose revetment blocks, is not taken into account in the available design guidelines. This increase should be investigated with the help of large scale model tests. For this purpose different types of the Verkalit $^{\circledR}$ revetment blocks, produced by the Berding Beton $\mathrm{GmbH}$, were used as examples of interlocking blocks. The horizontal interlocking of this block type is ensured by an innovative key and slot system (see Figure 1). The Large Wave Flume Hannover was chosen as the test facility.

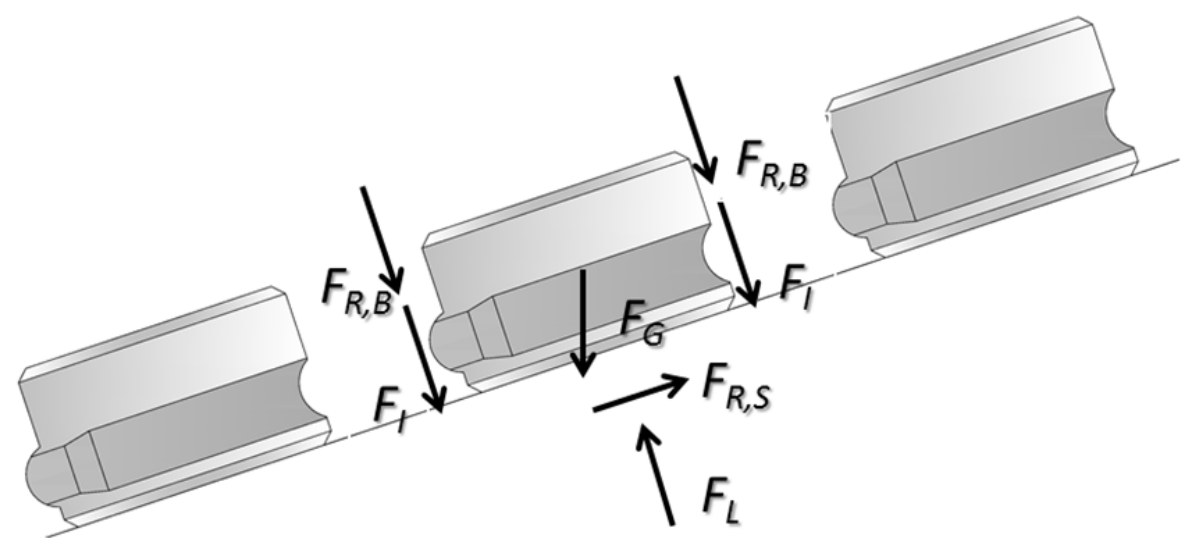

Figure 1. Active forces on a single interlocking revetment block

\section{Scientific Background}

The design of coastal revetments in Germany is performed on the basis of a number of special guidelines and regulations including EAK(2003), EAU (2004) or GBB (2010) which make use of the well known design formulas by Hudson (1959) and Van der Meer (1988) for rubble mound structures. For loose placed block revetments the design methods by Bezuijen et al. (1986), Burger et al. (1989), Klein Breteler \& Bezuijen (1992) or Pilarczyk (1992) are recommended.

Currently now no design guidelines are available in the associated literature for interlocked block revetments. The increase in stability of these kinds of revetments due to the interlocking force is not taken into account, although interlocking blocks have been in use in Germany and other countries for decades (Pilarczyk 1992, Gier et al. 2012). Experimental investigations for interlocking blocks were only performed by Wouters (1991) in small scale model tests to determine the resistance of interlocking blocks against wave attack. The transfer of the results by Wouters is uncertain due to model effects associated to the processes in the subsoil. Therefore, systematic and transferable investigations are required to investigate the effect of an interlocking system on the hydraulic stability of a coastal revetment. In addition, PIANC (2011) recommends such investigations for interlocking blocks.

\section{Model set-up}

Between November 2010 and March 2011, extensive large scale model tests were performed in the Large Wave Flume Hannover to determine the structural stability against wave attack of different types of the interlocked Verkalit ${ }^{\circledR}$ revetment blocks in a scale of 1:1 (see Figure 2). 

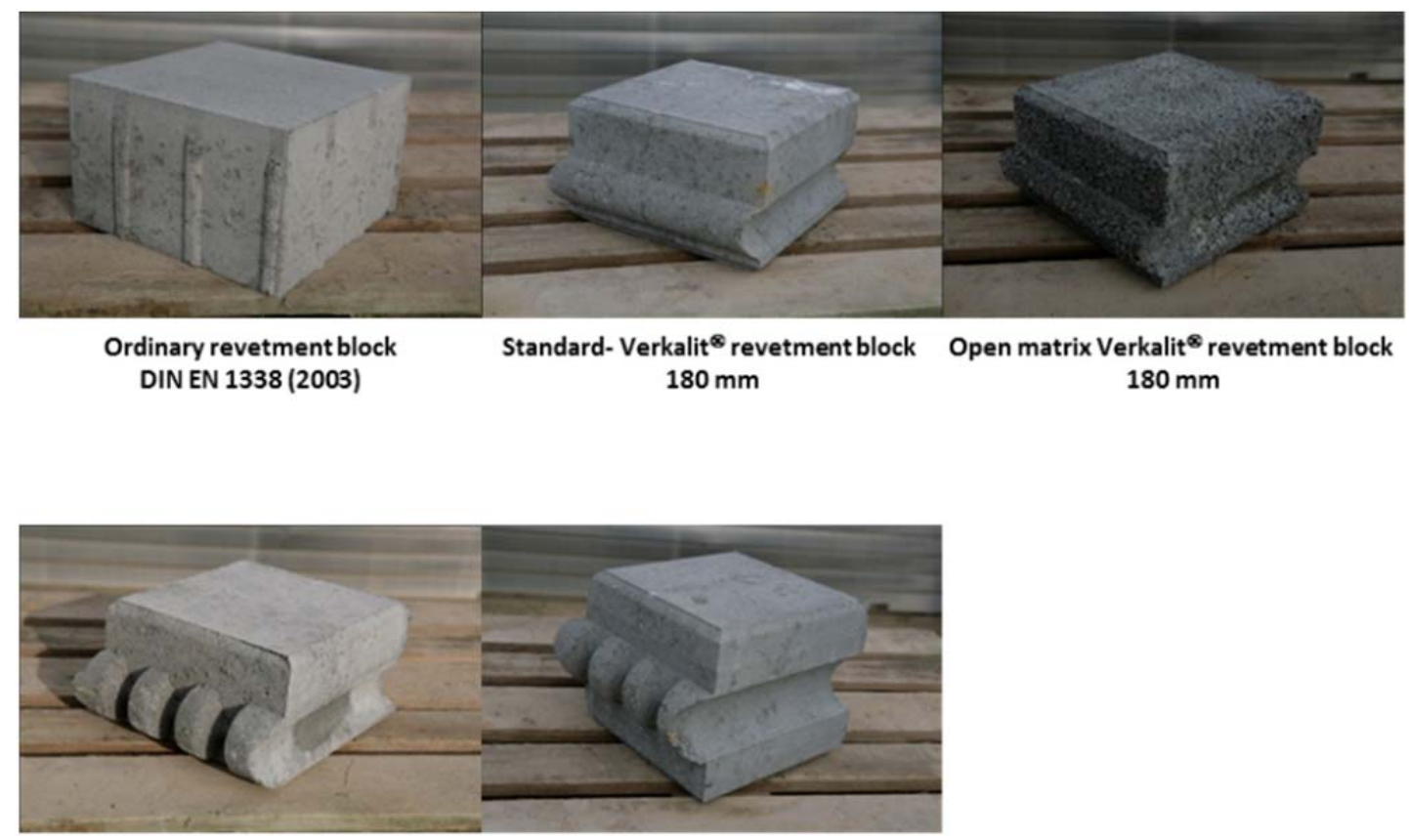

Modified Verkalit ${ }^{\star}$ revetment block Modified Verkalit ${ }^{\star}$ revetment block $180 \mathrm{~mm}$ $250 \mathrm{~mm}$

Figure 2. Reviewed Verkalit ${ }^{\circledR}$ revetment blocks

The 1:3 sloped revetment was constructed on an embankment made of a compressed sand core $\left(D_{50}=0.35 \mathrm{~mm}, D_{10}=0.19 \mathrm{~mm}\right.$ and $\left.U=D_{60} / D_{10}=0.38 / 0.19=2.0\right)$ with an estimated hydraulic conductivity of $k_{f}=1.0 \times 10^{-4} \mathrm{~m} / \mathrm{s}$. In order to investigate different revetment setups simultaneously, the slope was divided into two sections by a separation wall. The sequence of sublayers of the revetment was, except for model phase 4, identical in all series of the experiments. The profiled sand core was coated by a geotextile layer $\left(k_{f}=2.86 \times 10^{-3} \mathrm{~m} / \mathrm{s} ; \mathrm{O}_{90}=0.1 \mathrm{~mm}\right)$ in order to prevent erosion of the core material. The top of the geotextile layer was coated with a granular filter, which represented the supporting area of the investigated revetment blocks. The cover layer consisted of the revetment blocks presented in Figure 2. The opening ratios of these revetment blocks were $3.3 \%$ (loose revetment block according to DIN EN $1338180 \mathrm{~mm}$ ), $3.0 \%$ (Standard Verkalit ${ }^{\circledR}$ revetment block $180 \mathrm{~mm}$ ), $3.0 \%$ (Open matrix Verkalit ${ }^{\circledR}$ revetment block $180 \mathrm{~mm}$ ), $5.8 \%$ (Modified Verkalit ${ }^{\circledR}$ revetment block 180 $\mathrm{mm}$ ), $5.8 \%$ (Modified Verkalit ${ }^{\mathbb{R}}$ revetment block $250 \mathrm{~mm}$ ). Structural details of the revetments in the four experimental periods are given in Table 1. 


\begin{tabular}{|c|c|c|c|c|c|c|c|c|c|c|c|}
\hline \multirow{3}{*}{ 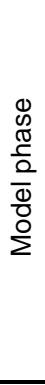 } & \multirow{3}{*}{ 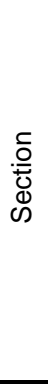 } & \multicolumn{5}{|c|}{ Revetment block } & \multicolumn{5}{|c|}{ Grain filter } \\
\hline & & Description & 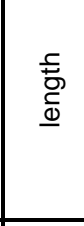 & $\frac{\frac{5}{6}}{\frac{0}{3}}$ & 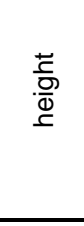 & $\frac{\frac{7}{5}}{\frac{D}{10}}$ & 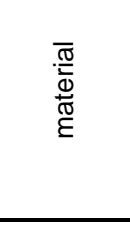 & $\begin{array}{l}\frac{\sigma}{0} \\
\frac{0}{0} \\
\overline{\frac{\pi}{\sigma}} \\
\frac{\pi}{\sigma}\end{array}$ & 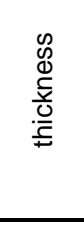 & 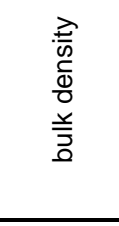 & $\begin{array}{l}\frac{\lambda}{5} \\
\frac{0}{0} \\
\frac{0}{2}\end{array}$ \\
\hline & & {$[-]$} & {$[\mathrm{mm}]$} & {$[\mathrm{mm}]$} & {$[\mathrm{mm}]$} & {$\left[\mathrm{kg} / \mathrm{m}^{2}\right]$} & {$[-]$} & {$[\mathrm{mm}]$} & {$[\mathrm{m}]$} & {$\left[\mathrm{kg} / \mathrm{m}^{3}\right]$} & [\%] \\
\hline 1 & 1 & $\begin{array}{c}\text { Standard } \text { Verkalit }^{\circledR} \\
\text { revetment block }\end{array}$ & 300 & 300 & 180 & 412.76 & Lime grit & 2 to 16 & 0.10 & 1731.00 & 17.65 \\
\hline 1 & 2 & $\begin{array}{c}\text { Ordinary revetment } \\
\text { block according to DIN } \\
\text { EN } 1338\end{array}$ & 300 & 300 & 180 & 412.76 & Lime grit & 2 to 16 & 0.10 & 1731.00 & 17.65 \\
\hline 2 & 1 & $\begin{array}{l}\text { Standard Verkalit } \\
\text { revetment block }\end{array}$ & 300 & 300 & 180 & 412.76 & Lime grit & 2 to 16 & 0.10 & 1731.00 & 17.65 \\
\hline 2 & 2 & $\begin{array}{l}\text { Open matrix Verkalit } \\
\text { revetment block }\end{array}$ & 300 & 300 & 180 & 483.36 & Lime grit & 2 to 16 & 0.10 & 1731.00 & 17.65 \\
\hline 3 & 1 & $\begin{array}{l}\text { Standard Verkalit } \\
\text { revetment block }\end{array}$ & 300 & 300 & 180 & 412.76 & Lime grit & 2 to 16 & 0.10 & 1731.00 & 17.65 \\
\hline 3 & 2 & $\begin{array}{l}\text { Modified Verkalit } \\
\text { revetment block }\end{array}$ & 300 & 300 & 180 & 401.84 & Lime grit & 16to 32 & 0.10 & 1589.00 & 23.65 \\
\hline 4 & 1 & $\begin{array}{l}\text { Modified Verkalit } \\
\text { revetment block }\end{array}$ & 280 & 280 & 250 & 518.76 & - & - & - & - & - \\
\hline 4 & 2 & $\begin{array}{l}\text { Modified Verkalit }^{\circledR} \\
\text { revetment block }\end{array}$ & 300 & 300 & 180 & 401.84 & Lime grit & 16 to 32 & 0.12 & 1589.00 & 23.65 \\
\hline
\end{tabular}

\section{Test program}

The model tests were performed with regular waves with a wave height $\mathrm{H}$ of up to $1.90 \mathrm{~m}$ and wave spectra (JONSWAP spectra) with a significant wave height $H_{S}$ of up to $1.4 \mathrm{~m}$. Due to shoaling effects, the maximum significant wave height $H_{S}$ raised up to $1.64 \mathrm{~m}$ at the foot of the revetment.

All tests with wave spectra comprised at least 1,000 waves. An overview of the test program with wave spectra is given in Table 2. To investigate the durability of the revetments, an additional long term test series was carried out with a duration of 8 hours. The long term tests consisted of the spectra JONSWAP D1, D2, D3 and D4 with a wave height $H_{S}$ of $1.4 \mathrm{~m}$, a wave period $T_{P}$ of $4.73 \mathrm{~s}$ and a duration of 2.0 hours each. 


\begin{tabular}{|c|c|c|c|c|}
\hline \multicolumn{5}{|c|}{ Table 2: Test program - wave spectra (Short term tests) } \\
\hline Test & Wave steepness $s_{0}$ & Wave height $H_{S}$ & Wave period $T_{P}$ & Wave lenght $L_{0}$ \\
& {$[\mathrm{~m}]$} & {$[\mathrm{m}]$} & {$[\mathrm{s}]$} & 30.00 \\
\hline JONSWAP 1 & 0.02 & 0.60 & 4.38 & 40.00 \\
JONSWAP 2 & 0.02 & 0.80 & 5.06 & 50.00 \\
JONSWAP 3 & 0.02 & 1.00 & 5.66 & 60.00 \\
JONSWAP 4 & 0.02 & 1.20 & 6.20 & 70.00 \\
JONSWAP 5 & 0.02 & 1.40 & 6.70 & 15.00 \\
JONSWAP 6 & 0.04 & 0.60 & 3.10 & 20.00 \\
JONSWAP 7 & 0.04 & 0.80 & 3.58 & 25.00 \\
JONSWAP 8 & 0.04 & 1.00 & 4.00 & 30.00 \\
JONSWAP 9 & 0.04 & 1.20 & 4.38 & 35.00 \\
JONSWAP 10 & 0.04 & 1.40 & 4.73 & 20.00 \\
JONSWAP Opt1 & 0.03 & 0.60 & 3.58 & 33.33 \\
JONSWAP Opt2 & 0.03 & 1.00 & 4.62 & 60.00 \\
JONSWAP Opt3 & 0.01 & 0.60 & 8.00 & 100.00 \\
JONSWAP Opt4 & 0.01 & 1.00 & & \\
\hline
\end{tabular}

In Figure 3 the chronological sequence of wave breaking (left), wave run-up (middle) and wave run-down (right) on a 1:3 sloped revetment in the Large Wave Flume Hannover is depicted.

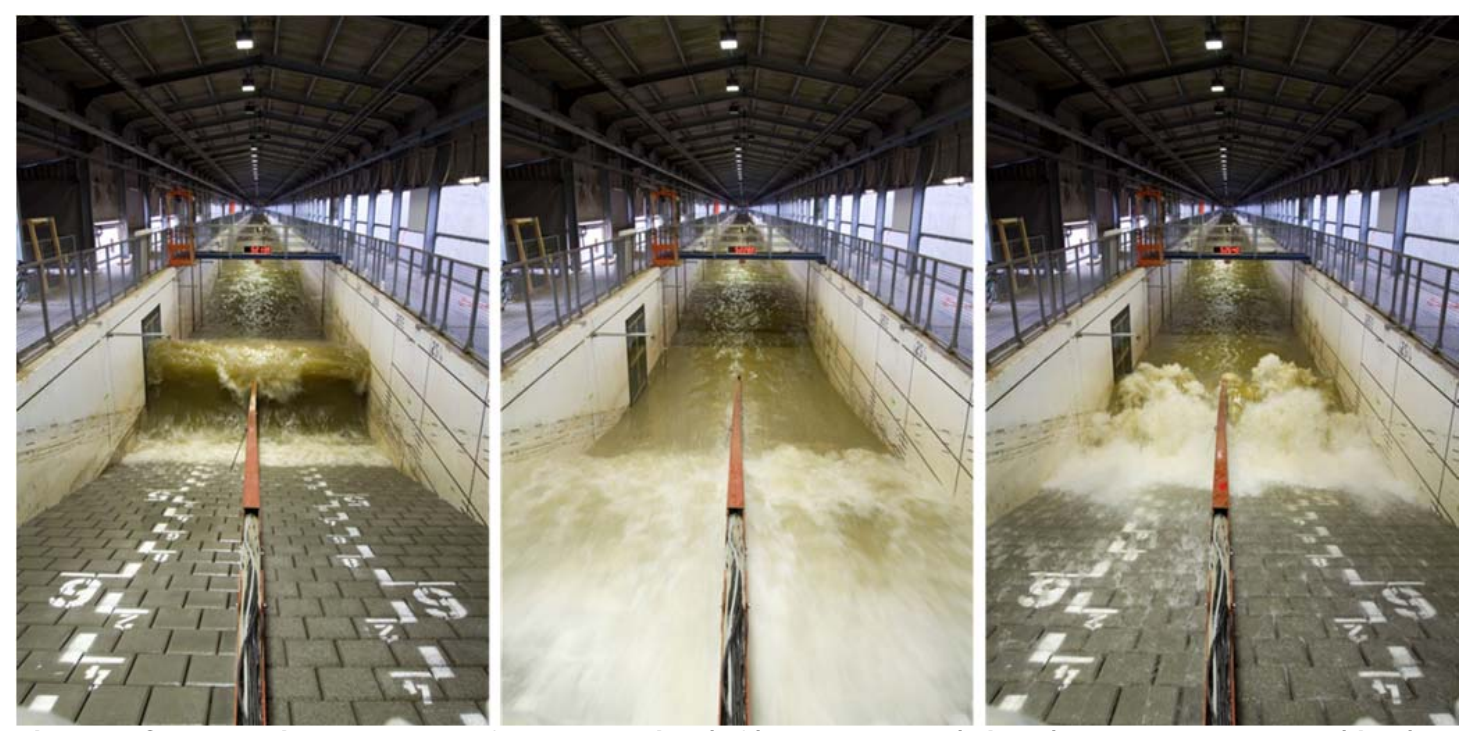

Figure 3. Chronological sequence of wave breaking (left), wave run-up (middle) and wave run-down (right) on a 1:3 sloped revetment in the Large Wave Flume Hannover

\section{Results of the experimental investigations}

The results of the large scale model tests are presented in the following text:

-Deformations of the revetment in the four model phases

- Stability parameter of the investigated revetment blocks

-Pull-out tests of the investigated revetment blocks

Generally, the visual appraisal of the deformations of a revetment after the wave loading is the first step in the assessment of the stability. For this reason it was necessary to determine the location of every single block before and after wave loading. The bottom of the wave flume was used as a 
reference for the determination of the elevation of the single blocks. Additionally, in order to determine the position of the gap between the blocks before and after loading, a tape measurement was made from the dike-crest. By calculating the difference between the original and the existing position, the movement of each single revetment block was detected. The results of the deformation measurements are summarized in Table 3. Due to a prematurely abortion of the test with the loose revetment blocks according to DIN EN 1338, no test results are available for this block in Table 3.

\begin{tabular}{|c|c|c|c|c|c|c|c|c|c|c|c|c|}
\hline \multirow[b]{3}{*}{ Description } & \multicolumn{6}{|c|}{ Settlement/ uplift [cm] } & \multicolumn{6}{|c|}{ Sliding $[\mathrm{cm}]$} \\
\hline & \multicolumn{2}{|c|}{$\begin{array}{c}\text { wave run-down } \\
\text { zone } \\
\end{array}$} & \multicolumn{2}{|c|}{$\begin{array}{l}\text { impact } \\
\text { zone }\end{array}$} & \multicolumn{2}{|c|}{$\begin{array}{l}\text { wave run-up } \\
\text { zone }\end{array}$} & \multicolumn{2}{|c|}{$\begin{array}{c}\text { wave run-down } \\
\text { zone }\end{array}$} & \multicolumn{2}{|c|}{$\begin{array}{l}\text { impact } \\
\text { zone }\end{array}$} & \multicolumn{2}{|c|}{$\begin{array}{l}\text { wave run-up } \\
\text { zone }\end{array}$} \\
\hline & avg. & $\max$ & avg. & $\max$ & avg. & $\max$ & avg. & $\max$ & avg. & $\max$ & avg. & $\max$ \\
\hline $\begin{array}{c}\text { Standard Verkalit }{ }^{\circledR} \text { revetment } \\
\text { block } 180 \mathrm{~mm}\end{array}$ & 0,6 & 1,9 & $-0,8$ & $-1,3$ & $-0,3$ & $-0,9$ & 0,2 & 0,8 & 0,4 & 1,2 & 0,4 & 0,7 \\
\hline $\begin{array}{l}\text { Open matrix } \text { Verkalit }^{\circledR} \\
\text { revetment block } 180 \mathrm{~mm}\end{array}$ & 0,1 & 1,1 & $-1,1$ & $-1,9$ & 0,3 & 0,8 & 0,5 & 1,0 & $-0,1$ & $-1,1$ & $-0,4$ & $-0,8$ \\
\hline $\begin{array}{c}\text { Modified Verkalit }{ }^{\circledR} \text { revetment } \\
\text { block } 180 \mathrm{~mm}\end{array}$ & 1,0 & 3,8 & $-1,9$ & $-3,4$ & $-0,6$ & $-1,2$ & $-0,4$ & $-1,7$ & $-0,3$ & $-1,8$ & $-0,8$ & $-1,6$ \\
\hline $\begin{array}{c}\text { Modified Verkalit }{ }^{\circledR} \text { revetment } \\
\text { block } 250 \mathrm{~mm}\end{array}$ & 0,7 & 2,6 & $-2,0$ & $-3,4$ & 0,0 & 0,3 & $-0,3$ & $-1,0$ & $-0,7$ & $-1,6$ & $-0,4$ & $-1,0$ \\
\hline
\end{tabular}

With the help of Table 3 it can be seen that the maximum settlements were about $+\backslash-3.8 \mathrm{~cm}$ and the maximum sliding was about $+\backslash-1.8 \mathrm{~cm}$. Obviously the deformations remain within reasonable limits.

Additionally, a typical appearance of deformations of a Verkalit ${ }^{\circledR}$ revetment due to wave loading is depicted in Figure 4. In the area of wave impact almost only settlements occurred, whereas in the area of wave rundown and wave run-up almost only uplifts can be observed. 


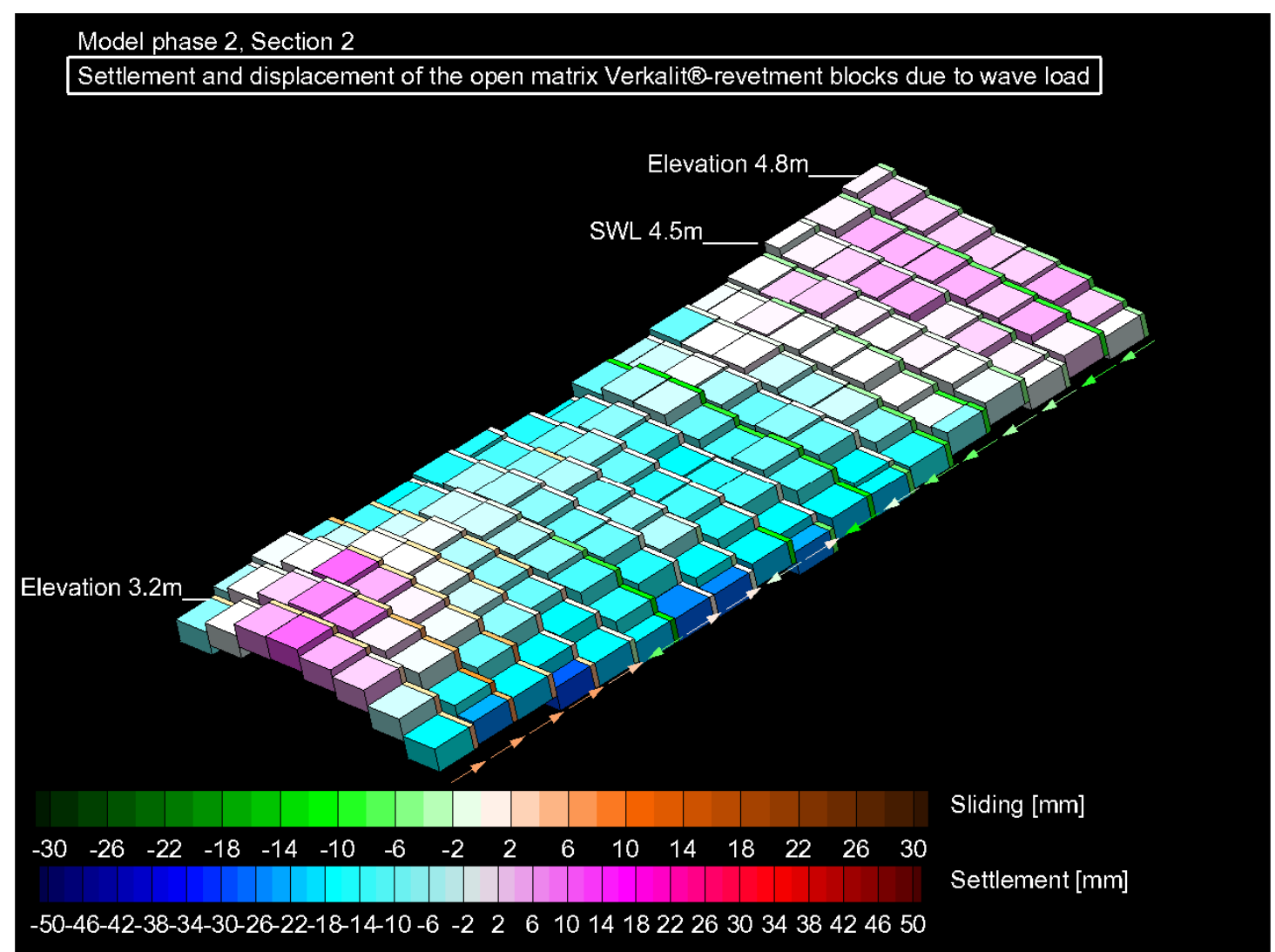

Figure 4. Typical results of deformation measurement

The assessment of the resistance of the revetment in mathematical terms is performed by the dimensionless stability coefficient $H_{S} /(\Delta D S)$ according to Pilarczyk (1992):

$$
\frac{H_{S}}{\Delta D_{S}}
$$

where $D_{S}[\mathrm{~m}]$ is the thickness of the placed block (20\% quintile), $H_{S}[\mathrm{~m}]$ the significant wave height and $\Delta[-]$ the relative density of the placed block, which is defined as follows:

$$
\Delta=\frac{\rho_{S}-\rho_{W}}{\rho_{W}}
$$

where $\rho_{S}\left[\mathrm{~kg} / \mathrm{m}^{3}\right]$ describes the density of the placed block and $\rho_{W}\left[\mathrm{~kg} / \mathrm{m}^{3}\right]$ the density of water. In combination with the dimensionless breaker parameter $\xi_{\text {op }}$, which contains the wave steepness $s[-]$ and the slope angle $\alpha\left[^{\circ}\right]$, the stability coefficient $H_{S} /(\Delta D S)$ [-] gives information about the resistance of the tested cover layer. The breaker parameter $\xi_{o p}$ is defined as:

$$
\xi_{o p}=\frac{\tan \alpha}{\sqrt{s}}
$$

In Figure 5 and Figure 6 the stability coefficient for regular waves (Figure 5) and wave spectra (Figure 6) is plotted against the breaker parameter $\xi_{o p}$. Each point in the diagram represents the maximum investigated load in the Large Wave Flume Hannover for the different types of revetment blocks. If no failure occurred during the test phase, it could be concluded, that the revetment blocks were able to resist wave loading up to this stability coefficient $\left(H_{S} /\left(\Delta D_{S}\right)\right)_{\max }$. For the area above the stability coefficient $\left(H_{S} /\left(\Delta D_{S}\right)\right)_{\max }$, no statement concerning the resistance could be made. 


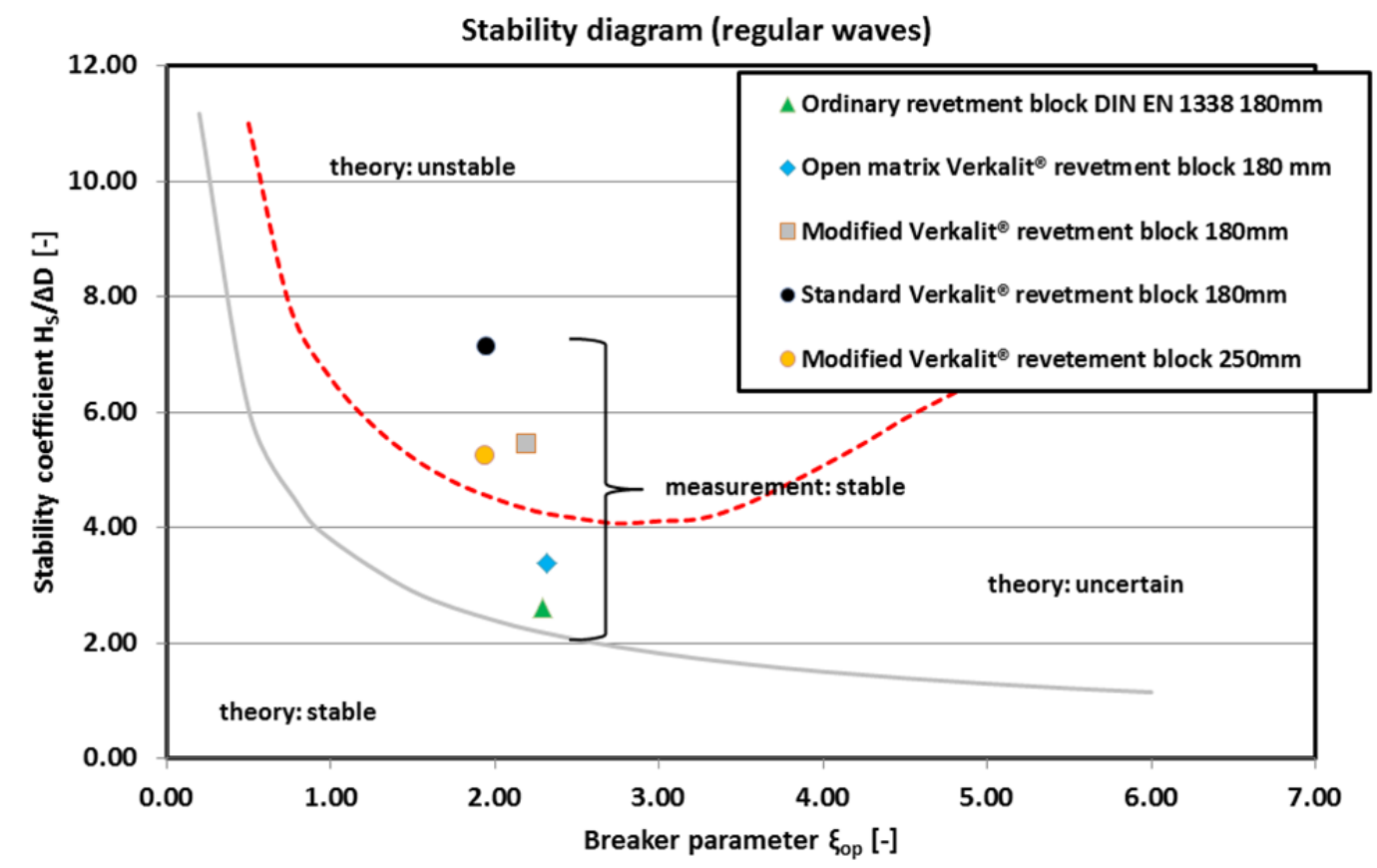

Figure 5. Stability chart of wave spectra (extended by Pilarczyk, 1992)

In the following paragraph, information about values of maximum stability coefficients is provided. They were obtained for regular waves and wave spectra, within which no significant deformations of the revetment structure during the model tests took place; namely no separation of single blocks out of the block layer could be identified (results for regular waves are given in brackets):

1. Ordinary revetment block according to DIN EN $1338180 \mathrm{~mm} \rightarrow\left(H_{S} /\left(\Delta D_{S}\right)\right)_{\max }=2.27(2.61)$

2. Standard Verkalit ${ }^{\circledR}$ revetment block $180 \mathrm{~mm} \rightarrow\left(H_{S} /\left(\Delta D_{S}\right)\right)_{\max }=7.08$ (7.12)

3. Open matrix Verkalit ${ }^{\circledR}$ revetment block $180 \mathrm{~mm} \rightarrow\left(H_{S} /\left(\Delta D_{S}\right)\right)_{\max }=5.39$ (3.39)

4. Modified Verkalit ${ }^{\circledR}$ revetment block $180 \mathrm{~mm} \rightarrow\left(H_{S} /\left(\Delta D_{S}\right)\right)_{\max }=6.99(5.45)$

5. Modified Verkalit ${ }^{\circledR}$ revetment block $250 \mathrm{~mm} \rightarrow\left(H_{S} /\left(\Delta D_{S}\right)\right)_{\max }=5.21$ (5.24)

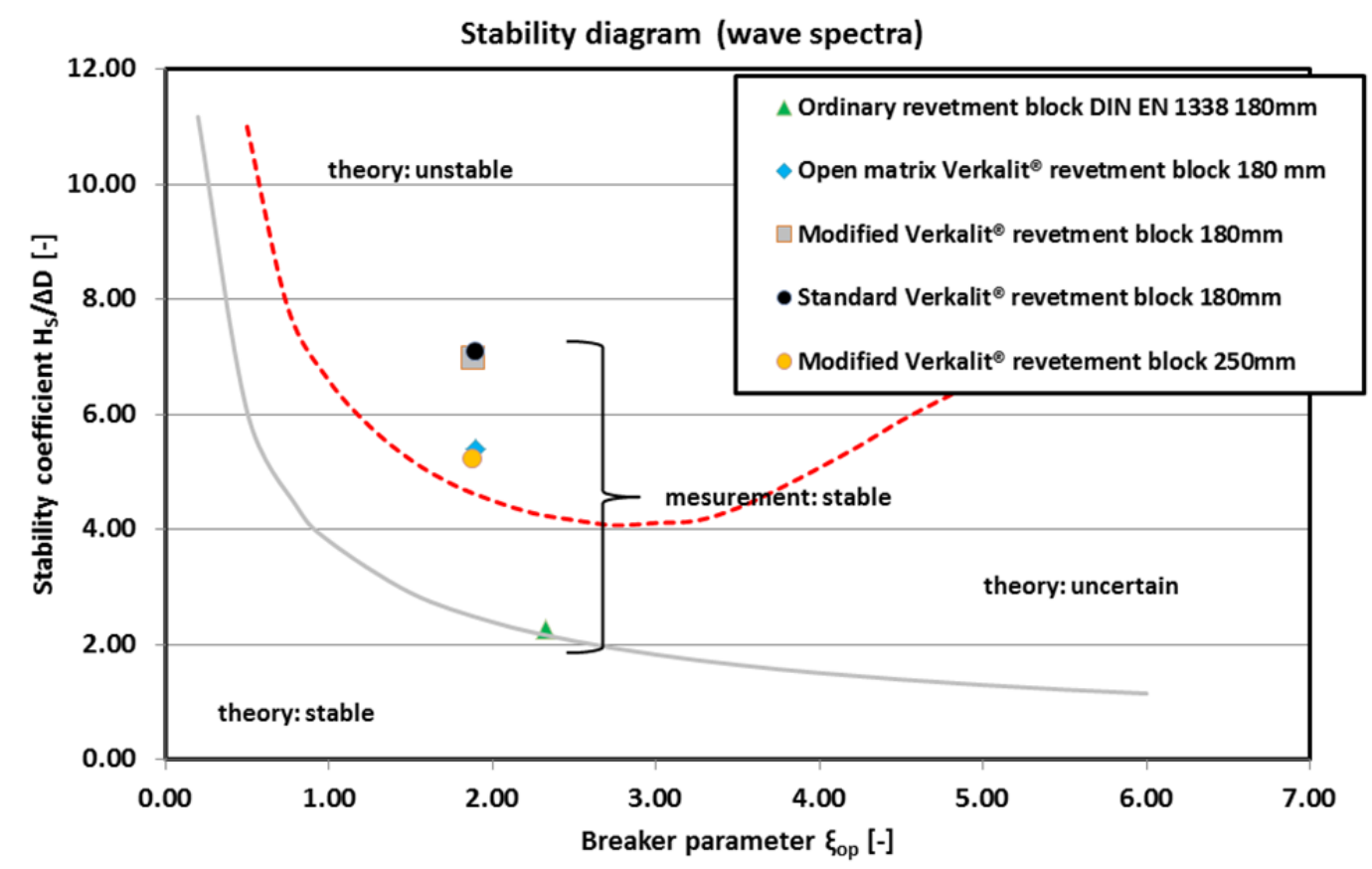

Figure 6. Stability chart of regular waves (extended by Pilarczyk, 1992) 
To create a visual comparison, the stability functions according to Pilarczyk (1992) were plotted (Figure 5 and Figure 6). They indicate that the ordinary revetment block according to DIN EN 1338 followed the theoretical calculation exactly (note: to protect the measuring instruments in the Large Wave Flume Hannover, the extraction of single blocks out of the revetment was not tolerated. The model tests for the ordinary revetment blocks according to DIN EN 1338 were stopped shortly before the loose revetment block failed. The data of this model test defines the failure point). In spite of the wave generator operating at its power limit, it was impossible to load the different types of the Verkalit ${ }^{\circledR}$ revetment blocks to the point of failure, although the theoretical stability coefficients indicate failure of common loose revetment blocks. This result implies the increase in stability by using the interlocking system, made of the key and slot system. The Standard Verkalit ${ }^{\circledR}$ revetment block as well as the modified Verkalit ${ }^{\circledR}$ revetment block reached a stability coefficient at least 2.3 times higher in comparison to the loose revetment block according to DIN EN 1338 without failing.

However in order to make a statement about the stability of the Verkalit ${ }^{\circledR}$ revetment blocks, pull out tests were performed. This test measured the force which is necessary to lift a single block out of the revetment structure. For this purpose dowels were placed in several revetment blocks and pulled out with the help of a crane after the end of each of the four model phases. The force, which increased constantly, was measured with a load cell. The chronological sequence of a pull out test is depicted in Figure 7.The measured force to release a single block can be considered as a reference value for the necessary uplift force needed to destroy the revetment.

In the pull out tests, attention was paid to select blocks from the area of wave run-down, the impact zone and the area of the wave run-up. Furthermore, care was taken to always select the blocks at identical locations in the different model phases.

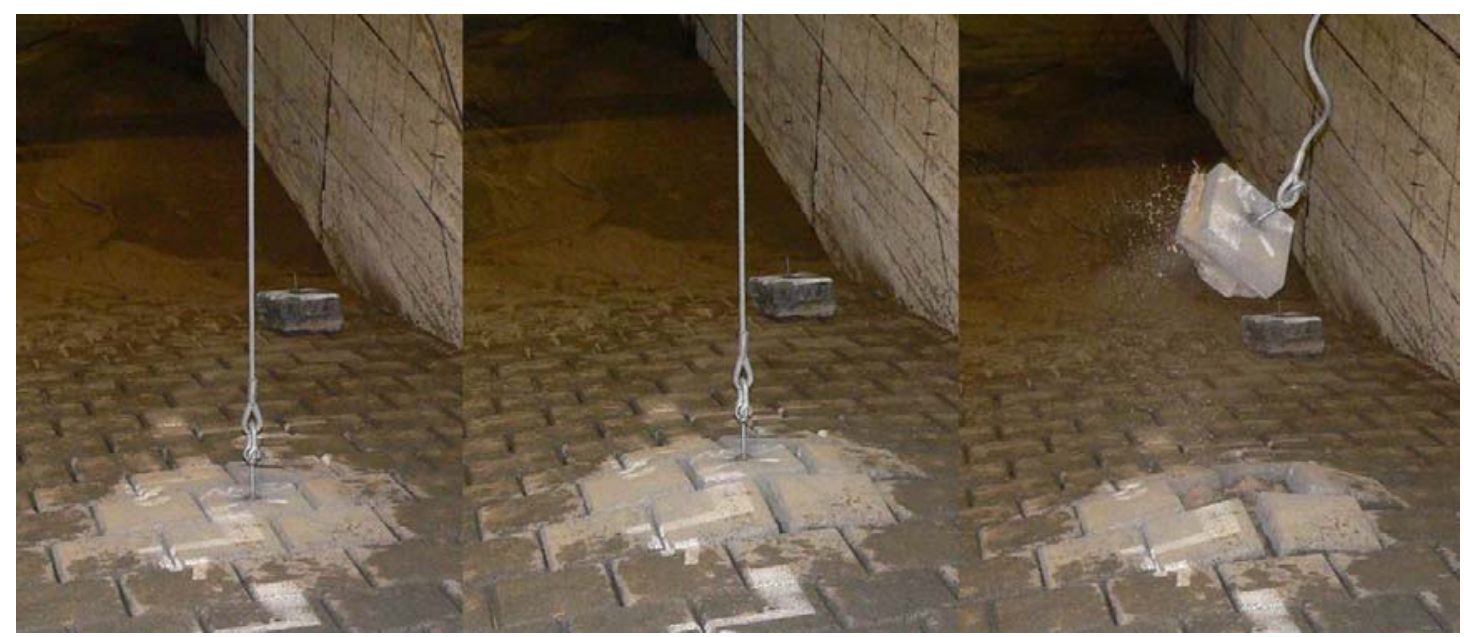

Figure 7. Chronological sequence of a pull out test

In Figure 8 the results of the pull out tests are given. For each investigated block the maximum force required to release a single block from the area of wave run-up, wave run-down and the impact zone was measured. Furthermore, the average required pulling force of the area of wave run-up and run-up is included in Figure 8. In comparison to the impact zone, the areas of wave run-up and wave run-down are not so heavily loaded. For that reason, these areas are henceforth referred to as the unloaded areas and the impact zone is termed the loaded area.

Figure 8 shows that the key and slot system of the Verkalit ${ }^{\circledR}$ revetment blocks increases the resistance significantly compared to a loose revetment block according to DIN EN 1338. To release the loose revetment block according to DIN EN 1338 from the structure, a pulling force of between $2.55 \mathrm{kN}$ (unloaded area) and $9.79 \mathrm{kN}$ (loaded area) was required.

In contrast, the Standard Verkalit ${ }^{\circledR}$ revetment block with a thickness of $180 \mathrm{~mm}$ required a pulling force of between $37.03 \mathrm{kN}$ (unloaded area) and $49.00 \mathrm{kN}$ (loaded area). These results differ by a factor 
of 14 for the unloaded area and a factor larger than 5 in the loaded area relating to the loose revetment block according to DIN EN 1338.

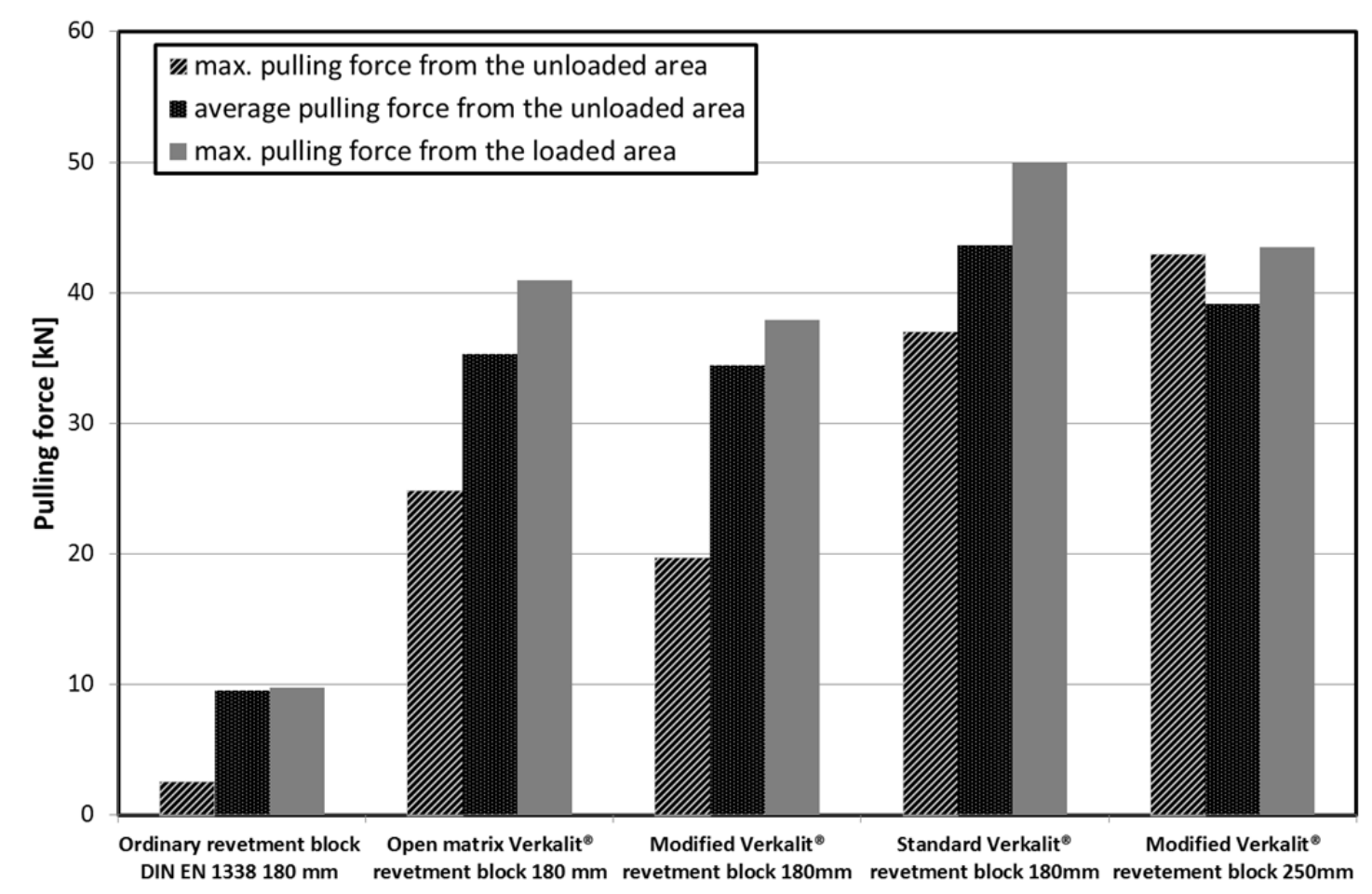

Figure 8. Required pulling forces from the pull out tests of the investigated blocks

\section{Conclusion}

Up to now, no scientific well-founded statement to the stability of interlocking blocks exists. The increase in stability due to an interlocking system is not taken into account in the design guidelines of the associated literature for placed block revetments. With the objective of quantifying this increase in stability, large scale model tests were performed in the Large Wave Flume Hannover.

Based on the test results, it can be proven that the stability number of the interlocked blocks is at least three times larger than the stability number of the loose revetment blocks according to DIN EN 1338. In contrast to loose revetment blocks according to DIN EN 1338 it was not possible to load the investigated interlocked blocks of the Verkalit ${ }^{\circledR}$ series to the point of failure despite operating the wave generator of the Large Wave Flume Hannover at its power limit. However, in order to make a statement about the stability of the revetment, pull out tests were performed. In these tests the force necessary to lift a single block out of the revetment structure was measured. These tests show that the necessary pulling force to release a single block is at least five times higher for the interlocked block than for a loose block.

\section{REFERENCES}

Bezuijen, A.; Klein Breteler, M.; Pilarczyk, K. W. (1986): Large-Scale Tests on a Block Revetment Placed on Sand with a Geotextile as Separation Layer. In: IIIrd Interna-tional Conference on Geotextiles, Vol. 2. Wien: Österr. Ingenieur- u. Architekten-verein, (Proceedings / IIIrd International Conference on Geotextiles / 7.-11.4.1986, Vienna/Austria ; Vol. 2; pp. 501-505.

Burger, A. M.; Klein Breteler, M.; Banach, L.; Bezuijen, A. (1989): Analytical design method for block revetments: paper presented at the 21th International Conference on Coastal Engineering, Malaga, Spain, 22 - 25 June 1988. / Burger, A. M. Delft: Delft Hydraulics Laboratory, (Publication / Delft Hydraulics Laboratory; 402; 
EAK (1993): Empfehlungen für Küstenschutzwerke. Empfehlungen E. Die Küste. Westholsteinische Verlagsanstalt Boyens \& Co. Heide in Holstein. Heft 55.

EAU (2004): Empfehlungen des Arbeitsausschusses Ufereinfassungen. Ernst \& Sohn Verlag

GBB (2010): Grundlagen zur Bemessung von Böschungs- und Sohlensicherungen an Binnenwasserstraßen. GBB. Ausgabe 2010. Bundesanstalt für Wasserbau http://www.baw.de/de/die_baw/publikationen/merkblaetter/index.php.html

Gier, F.; Mönnich, J.; Schüttrumpf, H.; van der Meer, J. (2012): Experimentelle Untersuchungen zur Stabilität von verzahnten Setzsteindeckwerken. KW Korrespondenz Wasserwirtschaft, Nr.5, Mai 2012; pp. 258-265, ISSN 1865-9926

Hansen, U. A. (1985): Wasserbausteine im Deckwerksbau : Bemessung und Konstruktion. Heide, Holstein: Westholsteinische Verlagsanstalt Boyens - ISBN 3-8042-0346-9

Hudson, R.Y. (1959): Laboratory Investigation of Rubble-Mound Breakwater. J. Waterways, Harbors Div., 85, ASCE, pp 93-121

Klein Breteler, M. u. Bezuijen, A. (1992): Simplified design method for block revetments. London: Telford, pp. 1-14. - ISBN 0-7277-1672-7

PIANC WG 57 (2011a): Stability of pattern placed revetment elements. Report of Expert Group 57, Bruxelles, Belgique

PIANC WG 128 (2011b): Alternative bank protection methods for inland waterways. Report of PIANC InCom WG 128 (Veröffentlichung in Vorbereitung)

Pilarczyk, K. W. (1992): Dutch experience on design of dikes and revetments. In: Coastal engineering practice '92 : proceedings of a Specialty Conference on the Planning, Design, Construction, and Performance of Coastal Engineering Projects, Long Beach, California, March 9 - 11, 1992 / Hughes, Steven A. New York, N.Y: ASCE, - ISBN 0-87262-866-3

Van der Meer, J.W. (1988): Rock Slopes and Gravel Beaches under Wave Attack. PhD-thesis Delft University of Technology. Also published as Delft Hydraulics Publications No. 396. 1988

Wouters, J. (1991): Taludbekledingen van gazette Steen. Grondmechanica Delft. Delft Hydraulics. M 1795/H 195 deel XXIII 